\title{
Preface
}

\section{Why Does College Matter?}

In order to talk about the role of extracurricular activities on the pathway to college, it is important to begin with the question we too often take for granted: Why would anyone want to go to college? You probably already know the answer: College matters because it is a key element in the class structure of the United States. Attainment of the relatively secure, wellcompensated jobs held by the upper middle class virtually requires a college education these days.

The typical young worker with a bachelor's degree earns significantly more than those who did not pursue any education beyond high school. In 2009, the average twenty-five- to twenty-nine-year-old with at least a bachelor's degree earned almost \$50,000 per year, while those who finished high school earned only about $\$ 31,000$ per year. The earnings of workers with less education, when compared to those of their more educated counterparts, tend not to grow as much as careers unfold. As a result, the difference in average earnings across education groups gets even larger as workers age. The typical adult with a bachelor's degree will earn $\$ 1.42$ million during a fortyyear career, compared with $\$ 770,000$ for a typical high school graduate. That $\$ 650,000$ difference narrows only marginally to $\$ 550,000$ after factoring in the expenses of going to college and the four years of potential earnings that college graduates give up while they are in school (Taylor 20II). 
This is the crux of the American Dream. This is how you get ahead-you work hard in school, you get good grades, you go to college, and you get on your way to living the good life. This is the story many of us heard growing up, and this, in turn, is the story we tell our children. In fact, among parents of a child age seventeen or younger, 94 percent say they expect their child to go to college (Taylor 20II).

So how does one get there? Before becoming a sociologist, if you had asked me how I got to college I would probably have begun the story with my senior year in high school when my mom took me to the bookstore and bought me a guidebook to the best three-hundred-and-something colleges in the United States. She instructed me to go through the book and, based on the profile of each school, pick five schools to apply to. I grew up in Oregon and was ready to try on a new place; thus, all of the schools I applied to were on the East Coast. I applied sight unseen. No one read over my personal essay or suggested I take a test preparation class for the SAT. After I learned where I had been admitted, my dad and I traveled east to tour the campuses. That is the story of how I got to college through the eyes of my seventeen-year-old self. I got good grades, I got good SAT scores, I wrote an essay, I went for a visit, and I made a choice. I worked hard, and I got ahead. This is the American Dream.

Unfortunately, my story suffers from a complete lack of what esteemed sociologist C. Wright Mills (2000) would call a "sociological imagination." Applying your sociological imagination means seeking out connections between your own life and the social context in which you are embedded. This is also spoken of as identifying the links between biography and history. For example, Mills cautions that rather than feeling like a personal failure for getting a divorce, use your sociological imagination to recognize that you live a society where half of all marriages end in divorce. How does our social structure make this possible? Historically speaking, how did we all come to be at this place together? As Mills wrote, "The first fruit of this imagination-and the first lesson of the social science that embodies it-is the idea that the individual can understand his own experience and gauge his own fate only by locating himself within his period, that he can know his own chances in life only by becoming aware of those of all individuals in his circumstances. In many ways it is a terrible lesson; in many ways a magnificent one." How then do we apply our sociological imaginations to this question of getting to college? 
First, we go back to the American Dream - that story about how the key to making it in this country is getting a bachelor's degree, that story about how 94 percent of parents expect their child to attend college (Taylor 20II), that story we have all heard about how if you just work hard enough you can make it in this country. But that story is not as true as some of us are taught to believe. Of any developed country, the United States has the greatest gap between expectations for college attainment and actual college attainment (Jerrim 2014). Most other countries are fairly well matched in terms of expectations and reality. But not the United States-our dearly held belief that anyone can achieve if they just work hard enough is not matched to our societal institutions. Rather, the American Dream masks drastic and growing inequalities.

We do not actually reside in a country where anyone who works hard enough can get ahead or where the most successful people in the room are always the most talented or the hardest working. We live in a country that was built through genocide, colonization, and slavery and has been largely governed through a system of upper-class white supremacy since its establishment. The list of government policies that have used socially constructed racial categories to selectively prohibit accumulation of income, wealth, property, health, human rights, safety, justice, and more is long and growing every day.

Our educational system is at the crux of this contradiction between our belief that anyone can get ahead and the ways our institutions practice stratification by race and class. Public schools were officially desegregated by mandate of the Supreme Court in the iconic Brown v. Board of Education decision of 1954. But it took two more decisions by the Supreme Court and nearly twenty years to actually begin to achieve integrated schools in the United States. And the public-particularly white homeownerscontinues to gravitate away from integration. Since the 1970s, schools, especially those that are no longer under court order to desegregate, have steadily resegregated (Reardon et al. 20I2). Currently the most segregated group in our society is white families with children (Frankenberg, Lee, and Orfield 2003).

As a result, racial inequality in our school system produces enormous differences in educational outcomes. Only 75 percent of Latino/as ages twenty-five to twenty-nine have a high school diploma, compared to 89 percent of blacks and 95 percent of whites, and only is percent of Latino/as have earned a bachelor's degree, compared with 23 percent of 
blacks and 40 percent of whites (Fry and Parker 2012). In other words, whites are nearly twice as likely as African Americans and almost three times as likely as Latino/as to attain a bachelor's degree or higher.

Part of this disparity, of course, is owing to other factors. The most reliable way to know how likely it is that a child will attend college is to learn their parents' level of educational attainment. If your parents did not go to college, regardless of your race, it is most likely that you will not go to college either (Reardon 20II).

Although race and class are intertwined, they are not the same thing. Each has independent effects. In comparison to white students whose parents did not go beyond high school, African American and Hispanic students drop out of college at higher rates-34 percent versus 27 percent of whites - and do not attain a bachelor's degree as often -8 percent versus I 4 percent of whites. At the other end of the parental education spectrum, racial differences are even more profound. Among students whose parents have attained at least a bachelor's degree, the statistics are even more striking: African American and Hispanic students do not attend college at twice the rate of similarly situated white students ( 15 percent versus 7 percent of whites), drop out of college much more often ( 37 percent versus 25 percent of whites); moreover, only 35 percent graduate with a bachelor's degree, relative to 58 percent of whites (Carnevale and Strohl 2013).

On top of race and parental education, growing segregation by income also contributes to unequal educational outcomes. In 1970, only is percent of families lived in neighborhoods classified as either affluent or poor; by 2007, 3I percent of families lived in such neighborhoods (Reardon and Bischoff 20II). Along with growing residential inequality we see a growing achievement gap. The gap between the children with family incomes in the top ro percent and children with family incomes in the bottom Io percent was about 40 percent wider in 2001 than in 1975 , and twice as large as the black-white achievement gap. (For reference, the 9oth income percentile was $\$ 165,000$ per family per year. The Ioth income percentile was at $\$ 15,000$ per family per year.)

Given these data, it is perhaps unsurprising to see how we as Americans compare to other countries with regard to the difference between professional and working-class children's plans to complete college versus the difference in their test scores. While professional and working-class children show very small differences in their plans to attend college, the differences in their academic achievement are quite large. Children of professionals 
on average score eight-tenths of a standard deviation higher than workingclass children in the United States. While other countries have even larger class-based differences in achievement, they are matched by differences in expectations (Jerrim 2014).

So how did I get to college? While hard work might be part of the equation, the fact that our societal institutions favor people like me made my journey much easier. I am white, I grew up in a middle-class family, in a home my parents owned, and in a neighborhood with very low rates of poverty and violence. I went to a very good public school with other middle- and upper-class white kids, and both of my parents are college graduates. In addition, I am a US citizen and had access to federal financial aid. I had no control over any of these things, and all played a large role in how I got to college.

It is no accident that our institutions of higher education are filled with people like me who have benefited from legacies of educational attainment. But why is there such a strong relationship between children's educational outcomes and parental race, education, and income? Why is there such a strong relationship even though we are taught to believe that everyone can achieve a college degree by applying a bit of effort?

One theory suggests that variation in educational attainment is essentially a cloak for preexisting class inequalities. This theory builds on Karl Marx's insights about the ways powerful groups in a society create systems that legitimate their own advantage. From this perspective, bachelor's degrees (and the coursework they represent) provide an appealing justification for the propensity of well-off parents to pass privilege along to their offspring. What about those who do not fit this pattern-the homeless-toHarvard stories? Reproduction theorists argue that those stories are actually essential to public acceptance of the whole regime; that is, the exceptions give the system the appearance of class neutrality.

Another answer to the question of why there is such a strong relationship between parental social class and children's educational outcomes harkens back to the work of sociologist Max Weber. This theory argues that modern societies have replaced traditional hierarchies of caste or tribe with hierarchies based on individual achievement. Thus, the ultimate worth of the college degree lies in the educational institution's ability to bestow advantages totally independent of a student's social background.

So which one is it? Does higher education simply sugarcoat existing inequalities in order to make privilege-laundering look legitimate? Or is 
the college degree a valid measure of individual merit? Lucky for us, many scholars have worked on these questions, and it turns out their findings are very consistent across datasets and methodologies. The answer is yes and yes: schooling does have independent effects on an individual's life chances, and at the same time educational credentials act as the paramount mechanism through which parents hand privilege down to their children (Stevens 2007).

But the landscape of higher education is changing, and mainly it is expanding. This means that the hoops privileged parents have to jump through to pass their privilege onto their children-and make it look like their kids earned it in a class-neutral system - are becoming more elaborate and more costly. Admissions offices' development of clear measures of accomplishment-standardized test scores, high school grade-point averages, athletic win records, counts of Advanced Placement classes, demonstrated artistic accomplishment, and formally recognized community service-have transformed the organization and culture of how we raise our children from the day that they are born. Indeed, the admissions criteria developed by elite colleges now act as the blueprint for childrearing in middle- and upper-class America (Lareau 2003; Stevens 2007). Parenting has become more competitive, more expensive, more structured around the production of demonstrated accomplishment, and, perhaps most consequential for the ideal of the American Dream, more and more difficult for middle- and lower-class families to match.

Not only is there growing income inequality, and upper-class families simply have more money than before-though that is part of the equation (Fry and Kochhar 2014) - the rub centers on how upper-class families are spending their money: they are increasingly dedicating their resources to ensuring their children's educational success-they are buying books, iPads, high-quality child care, summer camps, private lessons, tutors, traveling sports teams, and the list goes on. Over the last forty years, families in the top income quintile have increased the amount they spend on enrichment activities each year from $\$ 3,536$ to $\$ 8,872$ (in 2008 dollars) -an increase of nearly 150 percent. Meanwhile, families in the bottom income quintile have increased their spending on educational enrichment from $\$ 835$ to $\$ 1,315$ (in 2008 dollars) - a substantially smaller increase (less than 60 percent) and a much smaller dollar amount overall (Duncan and Murnane 2011). 
And why? College admissions offer a system, a game if you will. Like every other game, if you want to win you have to know not only the formal rules but also the strategy-that is, the unspoken rules. While the official rules of college admissions declare the importance of purportedly unbiased measures like standardized test scores, grades, and extracurricular accomplishments, privileged parents do things to put their children at the front of the pack. They make sure their kids are attending good schools in good neighborhoods, they purchase athletic gear and art supplies, they shuttle their minivans from band practice, to Girl Scouts, to ballet. They start early-in preschool even-intervening on behalf of their children in schools and other institutions to ensure the best possible outcomes and teaching their children that there is an exception to every rule (Lareau 2003).

Think about your own pathway to college. Who showed you the ropes? Did you consider not going to college? What kind of help did you get with preparation for standardized tests or essay writing? Did you participate in athletics? Arts? Yearbook? What kind of resources and transportation did these activities require? I was required to play team sports every season starting in elementary school, not to mention piano lessons, Sunday school, and summer camps. I did not have to give up extracurricular opportunities to care for my siblings, and I did not have to work for pay to keep my family afloat. When it came time to apply to colleges, my mom did not mention community college as a possibility. Instead, she bought me that book about the three-hundred-and-something best colleges, not coincidentally all four-year schools.

Thus, what are we to make of the fact that we are taught to believe that if you work hard, then you will get ahead-that those young people who do well in school are the smartest and hardest working kids in the crowdwhen we live in a country where higher education is doing more to replicate existing inequality than to eliminate it?

Is this a problem? I argue yes, partly for moral reasons. We, as a society, claim to value equal opportunity. But if that doesn't convince you, look at the data. Our society is becoming increasingly socioeconomically unequal and increasingly ethnically and racially diverse (Frey 201I). In 2010, among children age five and under, whites made up only about half of the population. Among school-aged children, one in four were Latina/o. The number of white students in our schools will continue to shrink as time passes. 
Increasing the number of black and Latina/o college graduates and the number of low-income college graduates must become a national priority.

For decades policy analysts and researchers have been trying to alleviate these troubling academic attainment gaps by focusing on schools-class size, teacher training, curriculum innovations, school choice-but with little success. The problem with this approach is that kids actually do not actually spend that much time in school; even counting homework time. Reed Larson and Suman Verma (1999) estimate that youth spend only 25 percent of their waking hours on school work. While public schools are incredibly unequal, what happens outside school accounts for much more of the variation in educational outcomes than what happens on the inside (Entwistle and Alexander 1992).

This book takes a closer look at the role extracurricular activities play in academic attainment. Researchers have linked participation in extracurricular activities to a plethora of positive outcomes, ranging from increased academic achievement to lower drop-out rates to stronger self-image. Most promising about extracurricular activities, however, is that disadvantaged students actually gain more from participation than their advantaged peers. Therefore, when disadvantaged youth participate, the attainment gap between students of high and low socioeconomic backgrounds begins to shrink. In other words, by giving disadvantaged students access to the same kinds of enrichment opportunities that privileged kids have, we can actually chip away at the educational attainment gap.

How do extracurricular activities - where youth arguably spend far less time than the formal school day-influence on educational outcomes? This book explores that question. By bringing to life the challenges that some Mexican American students face when navigating the intersections of drastically different home, school, and community spheres on their pathways to college, this book highlights the processes through which extracurricular contexts might play an important role in educational attainment for disadvantaged youth by whittling away at race- and class-based academic attainment gaps-gaps that have important implications for our society in the decades ahead. 